\title{
Reidentifikasi Konsep dan Teori Dalam Memahami Fenomena Blind Spot Penelitian Pariwisata di Bali
}

\author{
I Putu Anom ${ }^{\mathrm{a}, 1}$, I Gusti Agung Oka Mahagangga ${ }^{\mathrm{a}, 2}$, I Made Bayu Ariwangsa ${ }^{\mathrm{a}, 3}$, I Gusti Ayu Athina Wulandari ${ }^{\mathrm{b}, 4}$ \\ ${ }^{1}$ putuanom@unud.ac.id, ${ }^{2}$ okamahagangga@unud.ac.id, 3 bayu_ariwangsa@unud.ac.id, ${ }^{4}$ athinawulandari@warmadewa.ac.id \\ a Program Studi Sarjana Destinasi Pariwisata, Fakultas Pariwisata, Universitas Udayana \\ b Program Studi Ekonomi Pembangunan, Fakultas Ekonomi dan Bisnis, Universitas Warmadewa
}

\section{Abstract}

Tourism science has been recognized as a scientific discipline in Indonesia since 2008. However, because of this interdisciplinary and multidisciplinary genealogy, it creates many scientific problems. The purpose of this paper is to understanding concept and theory of tourism science that very complex. The research was conducted in Bali, using qualitative methodology with library study methods, observation and in-depth interviews. The technique of determining informants used purposive sampling and qualitative data analysis techniques. The results of the study show that the concepts and theories of tourism are still largely referring to previously established sciences with many borrowing concepts, theories and other scientific methods. This fact make "the big machine of concept and theory" trigger as a blind spot. Very natural for a new science with interest wide ranging subject / object of research. Such an approach, the research findings that blind spot phenomenon in tourism research can be solved. In the industrial revolution 4.0 era, for existence tourism science more research must produce new concepts, theories and innovations.

Keywords: Concept, theory, blind spot, science, tourism

\section{PENDAHULUAN}

Pada tahun 2008, untuk pertama kalinya studi pariwisata mendapat pengakuan sebagai ilmu pengetahuan di Indonesia. Presiden RI Susilo Bambang Yudhoyono melaunching Fakultas Pariwisata, Universitas Udayana, Bali sebagai satu-satunya Fakultas Pariwisata di Indonesia waktu itu. Setelah bertahun-tahun berjuang untuk mendapatkan pengakuan akademik, akhirnya ilmu pariwisata menjadi ilmu independen yang setara dengan ilmu-ilmu pengetahuan lain yang telah diakui selama puluhan atau ratusan tahun keberadaannya (Suryawan dan Mahagangga, 2017).

Mengacu pada pemahaman filsafat ilmu, ilmu pengetahuan harus memiliki ontologi, epistemologi dan aksiologi sebagai aspek-aspek yang membentuk ilmu pengetahuan. Ilmu pariwisata sudah memiliki aspek-aspek tersebut, hanya hal ini masih menjadi permasalahan. Mengingat ilmu pariwisata berawal dari ilmu yang bersifat interdispliner dan multidisipliner yaitu lebih banyak mengacu kepada ilmu-ilmu sosialhumaniora sejenis yang sudah terlebih dahulu terbukti kemapanan konsep dan teorinya seperti ilmu ekonomi, ilmu geografi, ilmu planologi, ilmu sejarah, ilmu antropologi budaya, ilmu sosiologi, ilmu psikologi dan ilmuilmu pengetahuan lainnya. Sehingga sangat banyak konsep-teori dari ilmu-ilmu yang sudah mapan tersebut diadopsi dengan perbedaan yang hampir tidak ada. Padahal eksistensi suatu ilmu pengetahuan dikarenakan memiliki kekhasan ontologi, epistemologi dan aksiologi yang membedakannya dengan ilmu lainnya (Suriasumantri, 1978; Prentice, 1990; Gie, 2014; Nugroho, 2017; Bakta, 2018).

Sebenarnya hal tersebut adalah hal wajar karena tidak ada ilmu pengetahuan yang taken for granted, melainkan selalui melalui proses mengacu kepada pemahaman ilmu pengetahuan sebelumnya sebagai suatu dialektika (Hegel dalam Ari Yuwana, 2010). Hanya perlu ditekankan adalah kesadaran reflektif ketika studi pariwisata telah diakui secara de jure oleh pemerintah RI seharusnya insan-insan akademis pariwisata di Bali khususnya (nBali sebagai laboratorium hidup pariwisata) semakin aktif melakukan penelitian-penelitian untuk menambah konsep, teori, inovasi dan novelty sebagai temuantemuan mutakhir yang dapat berguna secara 
akademis maupun praktis. Sehingga ilmu pariwisata akan semakin mampu menunjukkan eksistensi sebagai ilmu mandiri yang setara dengan science lain yang sudah terlebih dahulu diakui keberadaannya.

Oleh karena itu, artikel ini berupaya melakukan reidentifikasi konsep dan teori ilmu pariwisata di Bali yang berdasarkan pengalaman empiris, penelitian-penelitian S1, S2 dan S3 ilmu pariwisata serta publikasi di jurnal ilmiah. Ketiga komponen tersebut berupaya di-reidentifikasi untuk dapat dipahami arah dan upaya pengembangan ilmu pariwisata kedepan.

\section{TINJAUAN PUSTAKA}

Menajamkan pembahasan diperlukan serangakaian konsep dan teori sebagai dasar pijakan dan mempermudah dalam melakukan analisis. Berikut konsep dan teori yang digunakan dalam artikel ini yaitu Fenomena (Muhadjir, 1996), Grounded theory (Yin, 2003), Grand Theory, Middle Range Theory, Little Theory (Moleong, 2005; Ahimas Putra, 2007; Neuman, 2013), Identifikasi (Mahagangga dan Nugroho, 2017), Konsep (suryawan dan Mahagangga, 2017), dan Teori (Kerlinger, 1973 dalam Prajitno, 2013).

\section{METODOLOGI PENELITIAN}

kualitatif (Muhadjir, 2002), dengan menggunakan metode utama studi pustaka (Koenjaraningrat, 1997), metode observasi (Moleong, 2005), dan metode wawancara (Bungin, 2010). Teknik analisis data menggunakan teknik analisis data kualitatif (Muhadjir, 2002).

\section{HASIL DAN PEMBAHASAN}

Pada tahun 2008 ilmu pariwisata diakui sebagai ilmu pengetahuan di Indonesia, berdasarkan Keputusan Direktur Jenderal Pendidikan Tinggi Nomor 2425 / D / T / 2008 tanggal 29 Juli 2008 dan Keputusan Menteri Keuangan Universitas Udayana Nomor 347A / H14 / HK / 2008 tanggal 27 September 2008 tentang Pendirian Fakultas Pariwisata, Universitas Udayana. Kemudian diikuti oleh lembaga pendidikan sejenis di Indonesia seperti
Universitas Pancasila di Jakarta, STP Bali dan STP Bandung serta lembaga-lembaga pendidikan lainnya.

$$
\text { Lahirnya ilmu pariwisata }
$$

memberikan kepastian dan harapan untuk memajukan pembangunan sektor pariwisata Indonesia. Sebelumnya, pariwisata hanya diakui sebagai keterampilan yang mengarah ke pendidikan kejuruan (vokasi). Ketika diakui sebagai ilmu pengetahuan, pariwisata telah memiliki ontologi, epistemologi dan aksiologi kelimuan sebagai payung pelaksanaan Tri Dharma Perguruan Tinggi (Pendidikan, Penelitian dan Pengabdian) yang memiliki manfaat akademis maupun praktis sebagai sumbangan kepada masyarakat lokal, praktisi pariwisata, pemerintah, pemangku kepentingan termasuk secara tidak langsung para wisatawan.

Hasil penelitian menunjukkan serangkaian konsep terkait dengan topik penelitian (Sosial Budaya, EkonomiManajemen, Pemasaran, Pariwisata Alternatif dn Perencanaan-Pengembangan) yang digunakan oleh para akademisi termasuk mahasiswa pariwisata (gelar sarjana, pascasarjana sebagai magister dan program doktoral) di Bali, ketika mereka mengungkapkan, meneliti dan menganalisis pariwisata sebagai fenomena, masalah, atau objek penelitian disampaikan pada Matrik 1 . Kajian Identifikasi Konsep Ilmu Pariwisata di bawah ini: 
Matrik 1. Kajian Identifikasi Konsep Ilmu Pariwisata (KIKIP)

\begin{tabular}{|c|c|c|c|c|c|}
\hline Konsep & $\begin{array}{l}\text { Sosial } \\
\text { Budaya }\end{array}$ & $\begin{array}{l}\text { Ekonomi \& } \\
\text { Manajemen }\end{array}$ & Pemasaran & $\begin{array}{l}\text { Pariwi } \\
\text { sata } \\
\text { Altern } \\
\text { atif }\end{array}$ & $\begin{array}{l}\text { Perencanaan \& } \\
\text { Pengembangan }\end{array}$ \\
\hline Sumber Daya Pariwisata & $\sqrt{ }$ & $\sqrt{ }$ & & $\sqrt{ }$ & $\sqrt{ }$ \\
\hline Sumber Daya Manusia & $\sqrt{ }$ & $\sqrt{ }$ & & $\sqrt{ }$ & $\sqrt{ }$ \\
\hline Sumber Daya Budaya & $\sqrt{ }$ & & & $\sqrt{ }$ & $\sqrt{ }$ \\
\hline Sumber Daya Minat Khusus & $\sqrt{ }$ & $\sqrt{ }$ & $\sqrt{ }$ & $\sqrt{ }$ & $\sqrt{ }$ \\
\hline Fasilitas & & $\sqrt{ }$ & & $\sqrt{ }$ & $\sqrt{ }$ \\
\hline Utilitas & & $\sqrt{ }$ & & $\sqrt{ }$ & $\sqrt{ }$ \\
\hline Infrastruktur Pariwisata & & $\sqrt{ }$ & $\sqrt{ }$ & $\sqrt{ }$ & $\sqrt{ }$ \\
\hline Service Akomodasi & & $\sqrt{ }$ & $\sqrt{ }$ & $\sqrt{ }$ & $\sqrt{ }$ \\
\hline Food and Beverage Services & & $\sqrt{ }$ & $\sqrt{ }$ & $\sqrt{ }$ & $\sqrt{ }$ \\
\hline Aminitas dan Kelembagaan & $\sqrt{ }$ & $\sqrt{ }$ & $\sqrt{ }$ & $\sqrt{ }$ & $\sqrt{ }$ \\
\hline Produk dan Atraksi Wisata & $\sqrt{ }$ & $\sqrt{ }$ & $\sqrt{ }$ & $\sqrt{ }$ & $\sqrt{ }$ \\
\hline Art Shop-Souvenir & $\sqrt{ }$ & $\sqrt{ }$ & $\sqrt{ }$ & $\sqrt{ }$ & $\sqrt{ }$ \\
\hline Support Company Services & & $\sqrt{ }$ & $\sqrt{ }$ & $\sqrt{ }$ & $\sqrt{ }$ \\
\hline $\begin{array}{c}\text { Aksesibilitas dan Moda } \\
\text { Transportasi }\end{array}$ & & $\sqrt{ }$ & $\sqrt{ }$ & $\sqrt{ }$ & $\sqrt{ }$ \\
\hline Wisatawan & $\sqrt{ }$ & $\sqrt{ }$ & $\sqrt{ }$ & $\sqrt{ }$ & $\sqrt{ }$ \\
\hline Karakteristik & $\sqrt{ }$ & $\sqrt{ }$ & $\sqrt{ }$ & $\sqrt{ }$ & $\sqrt{ }$ \\
\hline Informasi dan Promosi & $\sqrt{ }$ & $\sqrt{ }$ & $\sqrt{ }$ & $\sqrt{ }$ & $\sqrt{ }$ \\
\hline Pemasaran dan IT & $\sqrt{ }$ & $\sqrt{ }$ & $\sqrt{ }$ & $\sqrt{ }$ & $\sqrt{ }$ \\
\hline MICE & $\sqrt{ }$ & $\sqrt{ }$ & $\sqrt{ }$ & $\sqrt{ }$ & $\sqrt{ }$ \\
\hline $\begin{array}{c}\text { Keamanan-Kenyamanan, Sadar } \\
\text { Wisata Desa Wisata }\end{array}$ & $\sqrt{ }$ & $\sqrt{ }$ & $\sqrt{ }$ & $\sqrt{ }$ & $\sqrt{ }$ \\
\hline Dampak Pariwisata & $\sqrt{ }$ & $\sqrt{ }$ & & $\sqrt{ }$ & $\sqrt{ }$ \\
\hline
\end{tabular}

Sumber : Hasil Penelitian, 2018

Sebenarnya konsep di atas masih memiliki banyak sub-sub konsep. Hanya konsep utama yang disajikan untuk memfasilitasi penyajian data. Seperti diuraikan pada Matrik 1. Kajian Identifikasi Konsep Ilmu Pariwisata (KIKIP) di atas, maka akan terlihat jelas sebagian besar konsep tersebut dominan digunakan dalam aspek pariwisata alternatif dan perencanaan pengembangan pariwisata. Hal ini menunjukkan bahwa ilmu pariwisata di Bali relatif besar perhatiannya pada pariwisata alternatif dan perencanaan pembangunan (termasuk dampak pariwisata). Jika diperhatikan, sebenarnya konsep-konsep di atas dapat berkorelasi dan digunakan dalam keseluruhan aspek aspek seperti sosio-budaya, aspek ekonomi, aspek pemasaran, aspek pariwisata alternatif dan aspek perencanaan pembangunan. Hanya dalam prakteknya, setiap konsep lebih fokus atau terfokus pada satu aspek dominan.

Contoh untuk konsep sumber daya pariwisata, lebih mengarah kepada dimensi perencanaan dan pengembangan. Dimensi ini mampu menjadikan sumber daya pariwisata sebagai potensi wisata yang layak untuk perencanaan kedepan. Artinya, dalam hal ini dimensi sosial budaya, dimensi ekonomi dan dimensi lainnya masih memiliki peran satu sama lain. Hal ini jelas menunjukkan bahwa dimensi perencanaan dan pengembangan ilmu pariwisata memiliki peran sentral dan hampir mencakup semua dimensi lainnya terutama untuk pengembangan sektor pariwisata.

Memperjelas pemahaman konsepkonsep pariwisata maka dapat dilihat pada Matrik 2. Kajian Konsep Ilmu Pariwisata (KKIP) yang sering digunakan dalam penelitianpenelitian pariwisata di Bali : 
Matrik 2. Kajian Konsep Ilmu Pariwisata (KKIP)

\begin{tabular}{|c|c|c|c|}
\hline Lingkup & Konsep & Fokus & Kriteria \\
\hline \multirow[t]{7}{*}{$\begin{array}{l}\text { 1. Elemen } \\
\text { Pariwisata }\end{array}$} & Sumber daya alam & $\begin{array}{l}\text { Iklim, Lokasi Geografis, Keindahan } \\
\text { Alam, Flora dan Fauna, Vegetasi, } \\
\text { Ekosistem Alami, Rekreasi Danau, } \\
\text { Rekreasi Sungai, Rekreasi Air } \\
\text { Terjun, Lintas Alam. }\end{array}$ & $\begin{array}{l}\text { Nama, bentuk kegiatan, } \\
\text { pengelola dan kondisi eksisting }\end{array}$ \\
\hline & $\begin{array}{l}\text { Sumber daya } \\
\text { manusia }\end{array}$ & $\begin{array}{l}\text { Transportasi, akomodasi, } F \& B \text {, } \\
\text { shoping, travel, attraction, } \\
\text { goverment, informal, kelembagaan, } \\
\text { Pokdarwis }\end{array}$ & 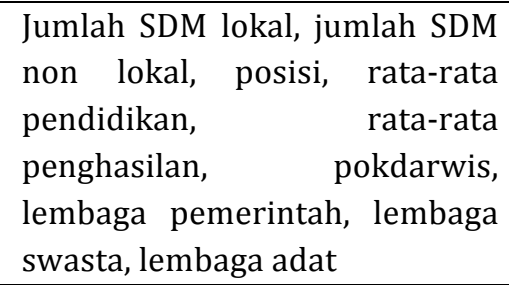 \\
\hline & $\begin{array}{l}\text { Sumber daya } \\
\text { budaya }\end{array}$ & $\begin{array}{l}\text { Way of life,Tradisi, aktivitas sosial } \\
\text { budaya, tinggalan purbakala dan } \\
\text { sejarah, arsitektur, seni lukis, seni } \\
\text { pahat, seni pertunjukan, } \\
\text { handycraft, souvenir, dan kuliner } \\
\text { lokal }\end{array}$ & $\begin{array}{l}\text { Nama, keunikan, bentuk } \\
\text { kegiatan, pengelola dan kondisi } \\
\text { eksisting }\end{array}$ \\
\hline & $\begin{array}{lr}\text { Sumber } & \text { daya } \\
\text { pariwisata minat } \\
\text { khusus }\end{array}$ & $\begin{array}{l}\text { Alam, budaya, buatan dan } \\
\text { gabungan }\end{array}$ & $\begin{array}{l}\text { Nama, keunikan, bentuk } \\
\text { kegiatan, pengelola dan kondisi } \\
\text { eksisting }\end{array}$ \\
\hline & Prasarana Wisata & $\begin{array}{l}\text { Jaringan transportasi jalan raya, } \\
\text { jaringan transportasi pelabuhan } \\
\text { udara, jaringan transportasi } \\
\text { pelabuhan laut, jaringan } \\
\text { transportasi stasiun, jaringan } \\
\text { transportasi informal, prasarana } \\
\text { perhubungan lain, utilitas }\end{array}$ & $\begin{array}{l}\text { Kuantitas, kualitas, listrik, air } \\
\text { bersih, telekomunikasi, drainase, } \\
\text { persampahan, pengolahan } \\
\text { limbah, pelayanan kesehatan } \\
\text { dan pelayanan lain }\end{array}$ \\
\hline & Sarana Wisata & $\begin{array}{l}\text { Jasa perusahaan angkutan wisata, } \\
\text { jasa penyediaan akomodasi, jasa } \\
\text { makanan dan minuman }\end{array}$ & $\begin{array}{l}\text { Perairan darat, perairan laut, } \\
\text { antar daerah, akupensi, fasilitas, } \\
\text { tenaga kerja, homestay, pondok } \\
\text { wisata, melati, berbintang, } \\
\text { higenitas, kapasitas, restoran, } \\
\begin{array}{l}\text { catering, warung makan, } \\
\text { pelayanan, }\end{array}\end{array}$ \\
\hline & $\begin{array}{l}\text { Penyelenggara } \\
\text { hiburan dan } \\
\text { rekreasi }\end{array}$ & $\begin{array}{l}\text { Natural site, natural event, cultural } \\
\text { site, cultural event, special event }\end{array}$ & Pengelola dan paket wisata \\
\hline 2.Daya tarik wisata & $\begin{array}{l}\text { Natural Site, natural } \\
\text { event, cultural site, } \\
\text { cultural event, } \\
\text { special event }\end{array}$ & Jenis atraksi dan jumlah operator & $\begin{array}{l}\text { Ciri khas, } \\
\text { kontemporer,something to see, } \\
\text { something to do, something to } \\
\text { buy, something to learn, } \\
\text { kreatifitas, inovasi dan } \\
\text { kenangan yang diperoleh } \\
\text { wisatawan }\end{array}$ \\
\hline $\begin{array}{l}\text { 3.Jasa souvenir-art } \\
\text { shop }\end{array}$ & $\begin{array}{lr}\text { Tipe } & \text { kerajinan } \\
\text { tangan tradisional- } & \\
\text { moderen, } & \text { tipe } \\
\text { tekstil, } & \text { tipe } \\
\text { peralatan, } & \text { tipe }\end{array}$ & $\begin{array}{l}\text { Pasar, komunal, koperasi, Bumdes, } \\
\text { mandiri, korporasi dan kerjasama }\end{array}$ & $\begin{array}{l}\text { Otentisitas, bauran, } \\
\text { kontemporer,postmoderen, } \\
\text { penyajian, hospitalitas dan } \\
\text { penjualan. }\end{array}$ \\
\hline
\end{tabular}


Vol. 7 No 2, 2019

\begin{tabular}{|c|c|c|c|}
\hline & $\begin{array}{l}\text { makanan dan } \\
\text { minuman,gabungan }\end{array}$ & & \\
\hline $\begin{array}{l}\text { 4.Jasa perusahaan } \\
\text { pendukung }\end{array}$ & $\begin{array}{ll}\text { Travel agent, } & \text { SPA, } \\
\text { rent car, rent } \\
\text { motorcycle, rent } \\
\text { bike, money changer }\end{array}$ & $\begin{array}{l}\text { Formal,informal,korporasi } \\
\text { komunal,koperasi, } \quad \text { Bumdes, } \\
\text { mandiri, dan kerjasama }\end{array}$ & $\begin{array}{l}\text { Utama,substitusi, } \\
\text { komplementer }\end{array}$ \\
\hline \multirow[t]{2}{*}{ 5.Aksesibilitas } & $\begin{array}{lr}\text { Sarana } & \text { menuju,di } \\
\text { lokasi daya tarik } \\
\text { wisata, } \\
\text { disekitar daya } \\
\text { wisata }\end{array}$ & $\begin{array}{l}\text { Sarana, petunjuk arah, moda } \\
\text { angkutan }\end{array}$ & $\begin{array}{l}\text { Jumlah,kondisi dan penggunaan, } \\
\text { waktu pengangkutan, kondisi, } \\
\text { lama perjalanan, harga jasa } \\
\text { angkutan, pengelola jasa } \\
\text { angkutan, trayek angkutan, } \\
\text { jumlah armada, kapasitas dan } \\
\text { kapabilitas operator angkutan }\end{array}$ \\
\hline & $\begin{array}{l}\text { Prasarana menuju, } \\
\text { di lokasi daya tarik } \\
\text { wisata dan disekitar } \\
\text { daya tarik wisata }\end{array}$ & Jalur jalan, pedestrian, trotoar & Jumlah, kondisi dan penggunaan \\
\hline 6.Wisatawan & $\begin{array}{l}\text { Domestik dan } \\
\text { mancanegara }\end{array}$ & $\begin{array}{l}\text { Tipe dan motivasi berwisata, minat } \\
\text { di daya tarik wisata serta daya beli }\end{array}$ & $\begin{array}{l}\text { Jumlah, waktu kunjungan, lama } \\
\text { kunjungan, } \\
\begin{array}{l}\text { kunjungan, karakter, spend of } \\
\text { money }\end{array}\end{array}$ \\
\hline $\begin{array}{l}\text { 7.Informasi dan } \\
\text { promosi daya } \\
\text { tarik wisata }\end{array}$ & $\begin{array}{l}\text { Citra/Branded, } \\
\text { strategi, promosi }\end{array}$ & $\begin{array}{l}\text { Guest comment/experience, } \\
\text { sasaran, target, dan strategi }\end{array}$ & $\begin{array}{lr}\text { Core product, manajemen } \\
\text { pemasaran,pangsa pasar, bentuk } \\
\text { pemasaran, bentuk promosi, } \\
\text { intensitas, media } & \text { yang } \\
\text { digunakan, harapan } & \text { waktu } \\
\text { kunjungan, fasilitas informasi } & \\
\text { dan promosi, lembaga khusus } \\
\text { informasi dan promosi. }\end{array}$ \\
\hline \multirow[t]{5}{*}{ 8.Bentuk pariwisata } & Pariwisata Individu & $\begin{array}{l}\text { Faktor budaya, faktor sosiologis, } \\
\text { faktor psikologis dan faktor } \\
\text { ekonomi }\end{array}$ & $\begin{array}{l}\text { Asal, jumlah, tipologi, karakter, } \\
\text { motivasi, persepsi, minat, } \\
\text { belanja, lintas budaya, kepuasan, } \\
\text { pengelolaan dan pengemasan }\end{array}$ \\
\hline & Pariwisata Kolektif & Idem & Idem \\
\hline & Pariwisata Budaya & 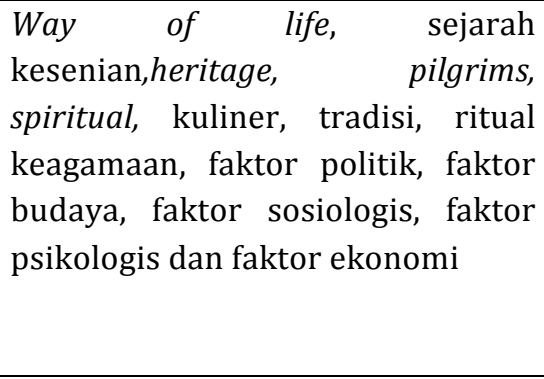 & $\begin{array}{l}\text { Otentisitas, keunikan, atraksi, } \\
\text { peraturan perundang-undangan, } \\
\text { kebijakan, pemerintah, praktisi, } \\
\text { masyarakat, Asal, jumlah, } \\
\text { tipologi, karakter, motivasi, } \\
\text { persepsi, minat, belanja, lintas } \\
\text { budaya, kepuasan, pengelolaan } \\
\text { dan pengemasan }\end{array}$ \\
\hline & Mass Tourism & $\begin{array}{l}\text { Pantai, danau, daya tarik wisata } \\
\text { alam, budaya dan buatan, MICE, } \\
\text { pusat perbelanjaan wisata-pasar } \\
\text { seni, klub malam, bar, hotel } \\
\text { berbintang, melati, pondok wisata, } \\
\text { restoran, travel agent. }\end{array}$ & $\begin{array}{l}\text { Asal, jumlah, tipologi, karakter, } \\
\text { motivasi, persepsi, minat, } \\
\text { belanja, lintas budaya, kepuasan, } \\
\text { pengelolaan, alam, buatan dan } \\
\text { pengemasan }\end{array}$ \\
\hline & Alternative Tourism & $\begin{array}{l}\text { Adventure, sport, afinity, romance, } \\
\text { jogging, tracking, hiking, cycling, } \\
\text { ATP, } z \text { zoo, }\end{array}$ & Idem \\
\hline
\end{tabular}


Vol. 7 No 2, 2019

\begin{tabular}{|c|c|c|c|}
\hline & & $\begin{array}{l}\text { hobi,kuliner,ekowisata,community } \\
\text { based tourism }\end{array}$ & \\
\hline \multirow[t]{2}{*}{ 9.Dimensi Ekonomi } & Makro & $\begin{array}{l}\text { Sistem Pariwisata, PAD, PDRB, } \\
\text { invisible export, kepuasan, daya } \\
\text { saing, daya beli, eksport-import, } \\
\text { kurs, kebocoran ekonomi, }\end{array}$ & $\begin{array}{l}\text { Kebijakan dan aturan, APBDN } \\
\text { APBD,APBDES,strategi-program } \\
\text { kerja pemerintah } \\
\text { produktifitas,pertumbuhan } \\
\text { ekonomi, location quotient, } \\
\text { bisnis, jumlah pengeluaran } \\
\text { wisatawan, penawaran dan } \\
\text { permintaan, pengaruh lama } \\
\text { tinggal wisatawan, perencanaan } \\
\text { dan pengembangan }\end{array}$ \\
\hline & Mikro & $\begin{array}{l}\text { Sektor usaha kecil, UMKM } \\
\text { pariwisata, koperasi Bumdes, }\end{array}$ & $\begin{array}{lrr}\text { Daya saing, inovasi, } & \text { peran } \\
\text { pemerintah, } & \text { permodalan } \\
\text { perencanaan } & \text { dan } \\
\text { pengembangan } & & \end{array}$ \\
\hline \multirow[t]{3}{*}{$\begin{array}{l}\text { 10.Dampak } \\
\text { pariwisata }\end{array}$} & $\begin{array}{l}\text { Dampak lingkungan } \\
\text { fisik }\end{array}$ & $\begin{array}{l}\text { Topografi, geologi, hidrologi, } \\
\text { klimatologi, } \text { ekosistem pantai, } \\
\text { daratan, danau, sungai, flora, fauna }\end{array}$ & Positif dan negatif \\
\hline & $\begin{array}{l}\text { Dampak lingkungan } \\
\text { sosial budaya }\end{array}$ & $\begin{array}{l}\text { Degradasi budaya, jumlah } \\
\text { penduduk, tingkat pendidikan, } \\
\text { umur, pekerjaan, asal daerah, } \\
\text { status, peran, interaksi, konflik, } \\
\text { seks, prostitusi, kenyamanan dan } \\
\text { kriminalitas }\end{array}$ & Positif dan negatif \\
\hline & Dampak ekonomi & $\begin{array}{l}\text { Pekerjaan, penghasilan, } \\
\text { pertumbuhan usaha jasa, industri } \\
\text { kecil, informal, koorperasi, } \\
\text { koperasi, Bumdes, PAD }\end{array}$ & Positif dan negatif \\
\hline $\begin{array}{l}\text { 11.Perencanaan \& } \\
\text { Pengembangan }\end{array}$ & $\begin{array}{lr}\text { Sejarah, } & \text { budaya, } \\
\text { politik, } & \text { sosial, } \\
\text { ekonomi, } & \text { tata } \\
\text { ruang, pemasaran } \\
\text { dan promosi }\end{array}$ & $\begin{array}{l}\text { Peraturan perundang-undangan, } \\
\text { kebijakan, peraturan desa, hukum } \\
\text { adat, kewilayahan, kawasan, } \\
\text { daerah, desa, produk, paket wisata, } \\
\text { jalur tracking, attraction, } \\
\text { accesability, amenities dan } \\
\text { ancillary, pemerintah, praktisi dan } \\
\text { masyarakat lokal }\end{array}$ & $\begin{array}{l}\text { Ripparda,masterplan, sitesplan, } \\
\text { actionplan, kajian akademis, } \\
\text { strategi-strategi pengembangan } \\
\text { dan program-program kerja } \\
\text { pembangunan pariwisata, }\end{array}$ \\
\hline
\end{tabular}

Sumber : Hasil Penelitian, 2018

Konsep-konsep ilmu pariwisata jelas menggambarkan ruang lingkup ilmu pariwisata yang luas dan kompleks. Bahkan berdasarkan Matrik 2. Kajian Konsep Ilmu Pariwisata (KKIP) terlihat keterpaduan sebagai state of the art ilmu pariwisata dalam melakukan analisis terhadap subyek (kualitatif) maupun obyeknya (kuantitatif). Jika disimak secara mendalam, keseluruhan konsep-konsep tersebut dipayungi oleh sistem besar yang mungkin dapat disampaikan sebagai payung ilmu pariwisata.

Berikut pada Matrik 3. Kajian TeoriTeori Ilmu Pariwisata (KTTIP) yang sering digunakan dalam kajian, penelitian maupun aplikasi (praktis) fenomena pariwisata di Bali : 
Vol. 7 No 2, 2019

\begin{tabular}{|c|c|}
\hline \multicolumn{2}{|r|}{ Matrik 3. Kajian Teori-Teori Ilmu Pariwisata (KTTIP) } \\
\hline Teori & Pakar \\
\hline Bentuk Pariwisata & Wahab (1976), Theobald (2005) \\
\hline $\begin{array}{l}\text { Motivasi } \\
\text { Berwisata }\end{array}$ & $\begin{array}{l}\text { McIntosh (1977), Dann (1977), Crompton (1979), Wickens (2002), , Yoeti } \\
\text { (1983) dan Spilane (1985) }\end{array}$ \\
\hline $\begin{array}{l}\text { Sumber Daya \& Produk } \\
\text { Pariwisata (Alam, } \\
\text { Budaya dan Buatan) }\end{array}$ & Freyer (1993), Smith (1994), Reid (2009), Cleere (1989), Boniface (2012), \\
\hline $\begin{array}{l}4 \text { A (attraction, accesable, } \\
\text { Amenities, Ancillary) } \\
\text { dalam Penawaran } \\
\text { Pariwisata, } \\
\text { pengembangan destinasi } \\
\text { Fasilitas Pariwisata, } \\
\text { Standar Fasilitas Wisata }\end{array}$ & $\begin{array}{l}\text { Medlik (1980), Lancaster (1983), Lawson dan Baud-Bovy (1997)Plog (2001), } \\
\text { (Yoeti, 2003), Baiquni dan Muhamad (2011) }\end{array}$ \\
\hline Dampak Pariwisata & $\begin{array}{l}\text { Smith (1977), Froment (1981), Geria (1983), Cohen (1984), Krippendorf } \\
\text { (1987), Mathieshon dan Wall (1990), Mantra dan Kutanegara (1990), } \\
\text { Erawan (1993), Tjatera (1994), Soekadijo (1995), Zeppel (1999), Stynes } \\
\text { (1999) Richardson dan Fluker (2004), Pitana dan Gayatri (2005), Diarta } \\
\text { (2006) }\end{array}$ \\
\hline $\begin{array}{l}\text { Pengembangan } \\
\text { Pariwisata }\end{array}$ & $\begin{array}{l}\text { Yoeti (1983), Murphy (1990), Lankford (2000), Mill (2000), Suwantoro } \\
\text { (2002), Madiun (2010) }\end{array}$ \\
\hline Citra Daya Tarik Wisata & Reynolds (1965), Cromton (1979), Selwyn (1996) \\
\hline $\begin{array}{l}\text { Pariwisata Alternatif dan } \\
\text { Lingkungan }\end{array}$ & $\begin{array}{l}\text { Yoeti (1984), Edington, John M, dan M Aan Edington (1986), Adam (1990), } \\
\text { Whellan (1991), Valene (1992), Smith dan Eadington (1992), Weiler dan } \\
\text { Halll (1992), Hunter dan Green (1995), Darsoprajitno (2002), Gunn (2002), } \\
\text { Ramly (2007), Sunarta (2015) }\end{array}$ \\
\hline $\begin{array}{l}\text { Wisatawan, Karakteristik } \\
\text { Minat Wisatawan, } \\
\text { Wisatawan Minat Khusus }\end{array}$ & $\begin{array}{l}\text { Cohen (1972), Plog (1972), Uriely (2001) Sheth, Newman dan Gross (1991), } \\
\text { Pritchard dan Pride (2004), March (2004), Melsen dan Murphy (2008), Read } \\
\text { (1980), Smith (1989), Hall dan Weiler (1992), Kadt (1992), Pintrich dan } \\
\text { Richardson dan Fluker (1994), Schunk (1996), }\end{array}$ \\
\hline $\begin{array}{l}\text { Interaksi, persepsi dan } \\
\text { sikap antara Host dan } \\
\text { Guest }\end{array}$ & $\begin{array}{l}\text { McKean (1973), Doxey (1976), Greenwood (1978), Erisman (1983), Nunes } \\
\text { (1989), Vickers (1989), Swarsi dan Geria (1995), McRae (1997),Yamashita } \\
\text { (2003, Shavit (2003) }\end{array}$ \\
\hline $\begin{array}{l}\text { Perencanaan, kawasan } \\
\text { dan tata ruang } \\
\text { kewilayahan Pariwisata }\end{array}$ & $\begin{array}{l}\text { Gunn (1988), Inskeep (1991), Gelebet (1999), Wiranatha dan Simth (2000), } \\
\text { Wiranatha (2001), Richardson dan Fluker (2004), Fandeli, 2002, Hadinoto } \\
\text { (1996), Supriyana (1997), Yoeti (1997), Suwardjoko, dkk. (2007), Paturusi } \\
\text { (2007), Paturusi (2008), Yoeti (2008), Wardiyanto dan Baiquni (2011) }\end{array}$ \\
\hline Ekowisata & $\begin{array}{l}\text { Butler dan Waldbrook (1991), Carter (1994), Hartato dan Insula (1995), Ross } \\
\text { dan Wall (1999), Bjork (2000), Yoeti (2000), Hall (2001) dan Wood (2002), } \\
\text { Juma dan Timer (2003), Hidayati (2003), Damanik dan Weber (2006), } \\
\text { Gossling (2007), Fodor dan Sitanyi (2008), Horton (2009), Nugroho (2011), } \\
\text { Arida (2016) }\end{array}$ \\
\hline $\begin{array}{l}\text { Ilmu Pariwisata, Faktor } \\
\text { Pendorong dan Faktor } \\
\text { Penarik Berwisata, Siklus } \\
\text { Hidup Destinasi Wisata }\end{array}$ & $\begin{array}{l}\text { Greenwood (1977), Norinha (1977), Stainfeld (1978), Butler (1980), Leiper } \\
\text { (1995), McIntosh (1980), Suwantoro (1997), Fennel (1999), Goeldner dan } \\
\text { Richardson dan Fluker (2004),Ritchie (2011) }\end{array}$ \\
\hline $\begin{array}{lr}\text { Keharmonisan } & \text { diri, } \\
\text { loyalitas } & \text { destinasi, } \\
\text { Pengunjung Pertama kali } \\
\text { dan repeater guest }\end{array}$ & $\begin{array}{l}\text { Gitelson dan Crompton (1984), Opperman (1997), Goh dan Litvin (2000), } \\
\text { Sirgy dan Su (2000), Liu, Lin dan Wang (2012) }\end{array}$ \\
\hline
\end{tabular}


Vol. 7 No 2, 2019

\begin{tabular}{|c|c|}
\hline $\begin{array}{l}\text { Geografi Pariwisata dan } \\
\text { Geowisata }\end{array}$ & $\begin{array}{l}\text { Pearce (1987), Sujali (1989), Soetomo (1990), Ramaini (1992), Sadry (2009), } \\
\text { Newsome and Dowling (2010), Subagio (2011), }\end{array}$ \\
\hline $\begin{array}{lr}\text { Politik, Kebijakan } \\
\text { Pariwisata dan Peran } \\
\text { Pemerintah }\end{array}$ & $\begin{array}{l}\text { Spillane (1991), Freeman (1996), Collin (1996), Hall dan Oehlers (2000), } \\
\text { Hermantoro (2011), Liu (1994), Bramwell dan Lane (2004), Dowling dan } \\
\text { Fennel (2003), Richardson dan Fluker (2004), Sunaryo (2013) }\end{array}$ \\
\hline $\begin{array}{l}\text { Ekonomi, Manajemen, } \\
\text { Bisnis Pariwisata }\end{array}$ & $\begin{array}{l}\text { Nehen (1970), Rodenburg (1980), Mathieson dan Wall (1982), Medlik } \\
\text { (1980), Erawan (1987), Smith (1988),Spilane (1987), Jackson (1989), } \\
\text { Brundtland (1991), Erawan (1994), Erawan (1999), Gitosarjono (1994), } \\
\text { Radiawan (1997), Lundberg, Stavenga dan Khrishnamoorthy (1997), Antara } \\
\text { (1999), mill (2000), Wong (2004), Bhatia (2006), Biederman, dkk. (2007), } \\
\text { Yoeti (2008), Bendesa, dkk., (2014), Wiranatha dan Suryawardani (2015) }\end{array}$ \\
\hline Antropologi Pariwisata & $\begin{array}{l}\text { Mc Kean (1973), Bagus (1975), Greenwood (1977), Smith (1982), Bagus } \\
\text { (1983), Krause (1988), Geria (1989), Geria (1995), Nash (1996), Soemardjan } \\
\text { dan Bagus (1997), Burns (1999), Yamashita (2003), Pitana (2004), Cole } \\
\text { (2005), Bruner (2005), Chamber (2009), Smith (2012), Salazar dan Graburn } \\
\text { (2014), Munster dan Melkert (2015) }\end{array}$ \\
\hline Sosiologi Pariwisata & $\begin{array}{l}\text { Cohen (1972), Ryan (1991), Wang (1999), Urry (2002), Spillane (2003), } \\
\text { Sharma (2004),Lynch (2005), Pitana dan Gayatri (2005), Soemanto (2010), } \\
\text { Baskoro (2010) }\end{array}$ \\
\hline 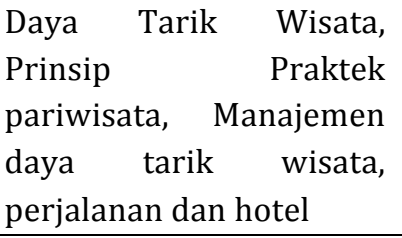 & $\begin{array}{l}\text { Manuaba (1982), Cox (1985), Cooper (1989), Leiper (1990), Yoeti (1992), } \\
\text { Musanef, Liu (1994), (1995), Wahab (1999), Marapaung (2002), Yoeti } \\
\text { (2002),Damanik dan Weber (2006), Ryan (2002), Baiquni (2004), Anshori } \\
\text { (2010), Penner, dkk., (2013) }\end{array}$ \\
\hline $\begin{array}{l}\text { Pariwisata } \\
\text { Arkeologi, } \\
\text { Otentisitas } \\
\text { Perubahan }\end{array}$ & $\begin{array}{l}\text { McKean (1973), Bandem (1983), Redfoot (1984), Yoeti (1985), Dibia (1985), } \\
\text { Cohen (1988), Dibia (1990), Mantra (1991), Nuryanti (1993), Wood (1993), } \\
\text { Dibia (1994), Boniface (1995), Kahn (1995), Lim (1996), Borley (1996), } \\
\text { Sutaba (1998), Richards (1999), Sedyawati (1999), Ardika (2003), Ardika } \\
\text { (2004), Sedyawati (2004), Yoeti (2006), Picard (2006), Pitana (2006), Ardika } \\
\text { (2007), Setyadi (2007), Wang (2007), Knudsen dan Waade (2010), Dibia } \\
\text { (2012), }\end{array}$ \\
\hline $\begin{array}{l}\text { Pemasaran dan Promosi } \\
\text { Pariwisata }\end{array}$ & $\begin{array}{l}\text { Schmoll (1977), Plog (1991), Holloway dan Robinson (1995), Yoeti (1996), } \\
\text { Cahcko (1997), Yoeti (2001), Darling (2001), Anshori (2002), Pike dan Ryan } \\
\text { (2004), Jenkins (2003), Dewi (2011), Diarta, dkk. (2015), Sudiarta dan } \\
\text { Suardana (2015), Sudiarta, dkk. (2014), Ali (2015) }\end{array}$ \\
\hline Anatomi Pariwisata & Soekadijo (1995), Yoeti (1996) \\
\hline $\begin{array}{l}\text { Sejarah dan } \\
\text { Perkembangan } \\
\text { Pariwisata }\end{array}$ & $\begin{array}{l}\text { Hartono (1974), Spillane (1989), Vickers (1989), Khodyat (1996),MacDonald } \\
\text { (2004), Macleod (2004), Theoblad (2005), Smith dan Robinson (2006), } \\
\text { Vukonic (2012), Simanjuntak, dkk. (2017), Putu Anom, dkk. (2017). }\end{array}$ \\
\hline Gastronomi Kuliner & $\begin{array}{l}\text { Hobsbwam dan Ranger (1983), Edwards et.al (2000), Hjalager dan } \\
\text { Corigliano (2000), Riley (2000), Hjalager dan Richards (2002), Frochot } \\
\text { (2003), Horner dan Swarbrooke (2008), Middletown, dkk., (2009),Zaenal, } \\
\text { dkk,, (2010), Landono, Ardika (2011), (2012), Darma Putra (2014) }\end{array}$ \\
\hline Psikologi Pariwisata & $\begin{array}{l}\text { Ross (1998), Perdue, dkk., (2004),Hermansyah (2007), Reseinger (2009), Rio } \\
\text { Budi Parsaja Tan (2009) }\end{array}$ \\
\hline MICE & $\begin{array}{l}\text { Fenich (1992), Pendit (1999), Lawson (2000), Kesrul (2004), March dan } \\
\text { Woodside (2005), Bowdin (2006), Getz (2006), }\end{array}$ \\
\hline $\begin{array}{l}\text { Keselamatan dan } \\
\text { keamanan wisatawan }\end{array}$ & $\begin{array}{l}\text { Pizam dan Mansfeld (1996), Chiang (2000), Elsrud (2001), Hitchook dan } \\
\text { Darma Putra (2005), (Adom, dkk., (2012), Gromang (2002), Khalik (2014), } \\
\text { Ayob, dkk. (2014) }\end{array}$ \\
\hline Usaha Perjalanan Wisata & Holloway (1993), Puslitbang Ekonomi (PEP) dan LIPI (1995), Samsuridjal \\
\hline
\end{tabular}


Vol. 7 No 2, 2019

\begin{tabular}{|c|c|}
\hline & $\begin{array}{l}\text { (1996), Williams dan Lew (1998), Foster (2000), Braidwood, dkk., (2000), } \\
\text { Swarbrooke dan Horner (2001), Sirait, Sirait dan Benjamin (2002), Bhatia } \\
(2006)\end{array}$ \\
\hline $\begin{array}{l}\text { Hukum } \\
\text { Pariwisata }\end{array}$ & $\begin{array}{l}\text { Goodall (1994), Wyasa Putra, dkk. (2003), Ningrum (2004), Gelgel (2006), } \\
\text { Simatupang (2009), }\end{array}$ \\
\hline Teori Pariwisata & $\begin{array}{l}\text { MacChannell (1976), Inskeep (1991), Cohen (1995), Wahab (1996), Yoeti } \\
\text { (1997), Pendit (1999),Yoeti (2001), Cooper, dkk., (1999), Hall (2003), } \\
\text { Mangiri (2003), Gamal Suwantoro (2010), }\end{array}$ \\
\hline $\begin{array}{l}\text { Teori dan Praktik } \\
\text { Akuntansi Perhotelan }\end{array}$ & Soewirjo (2003), Prastowo, Darminto, Suryo (2005) \\
\hline $\begin{array}{l}\text { Pariwisata } \\
\text { kemiskinan }\end{array}$ & $\begin{array}{l}\text { Poultney dan Spencenley (2001), Ashley dan Roe (2002), Jamieson, Goodwin } \\
\text { dan Edmunds (2004), Damanik, dkk. (2005), Harison (2008), Gibson (2009), } \\
\text { Hill, Nell dan Trotter (2006) }\end{array}$ \\
\hline $\begin{array}{lr}\text { Komunikasi } & \text { dan } \\
\text { Pemahaman } \quad \text { Lintas } \\
\text { Budaya Pariwisata }\end{array}$ & Syam, (2010), Kusherdyana (2011) \\
\hline $\begin{array}{l}\text { Filsafat Pariwisata dan } \\
\text { Postmoderen Pariwisata }\end{array}$ & $\begin{array}{l}\text { Berger (1972), Foucault (1972), Sarbini Mbah Ben (2010), Prasiasa (2011), } \\
\text { Bourdieu (1986), Naisbitt (1994), Tribe (2009), Nugroho, dkk. (2017) }\end{array}$ \\
\hline Pariwisata Perdesaan & $\begin{array}{l}\text { Lane (1994), Aroonson (1994), Wall (1995), Nasikun (1997), Page dan Getz } \\
\text { (1997), Wilson, Fesenmaier dan Van Es (2001), Robert dan Hall (2004), Liu } \\
\text { (2006), Haven Tang dan Jones (2012) }\end{array}$ \\
\hline $\begin{array}{l}\text { Partisipasi Masyarakat } \\
\text { Lokal dan CBT }\end{array}$ & $\begin{array}{l}\text { Gunn (1972), Murphy (1985), Korten (1986), Inskeep (1991), Korten (1991), } \\
\text { Timothy (1993), Woodly (1993), Pretty (1995), REST (1997), Timothy } \\
\text { (1999), Tosun (1999), Hausler (2000), Garrod (2001), Natori (2001), } \\
\text { Nasikun (2001), Liu (2003), Suansri (2003), Beaton (2006), Tosun (2006), } \\
\text { Telfer dan Sharpley (2008), Simpson (2009), Matarrita-Cassante (2010), } \\
\text { Davies (2011), Hermantoro (2011) }\end{array}$ \\
\hline Pariwisata Berkelanjutan & $\begin{array}{l}\text { Eadington dan Smith (1992), Smith (1994), Mitlin (1992), Nelson, Butler dan } \\
\text { Wall (1993), Wall (1993), Hunter (1997), Burns dan Holden (1997), } \\
\text { Mowforth dan Ian Munt (1998), Arronsson (2000), Swarbrooke (2002), } \\
\text { Nasser (2003), Dwyler dan Edward (2010), Cohen (2010) }\end{array}$ \\
\hline $\begin{array}{ll}\text { Mitigasi } & \text { Kebencanaan } \\
\text { Pariwisata } & \end{array}$ & $\begin{array}{l}\text { Murphy dan Bayley (1989), Fairbairn, 1997), Huang dan Min (2002), } \\
\text { Kokelaar (2002), Benediktsson, dkk. (2011) }\end{array}$ \\
\hline Pariwisata Minat Khusus & Weiler dan Hall (1992), Novelli (2005), \\
\hline Gender Pariwisata & Urry (1991), Scheyvens (2000), Tucker dan Boonabaana (2012) \\
\hline $\begin{array}{l}\text { Pariwisata Sejarah, } \\
\text { Heritage, wisata religi } \\
\text { dan Pilgrims }\end{array}$ & $\begin{array}{l}\text { Runcie (1988), Pendit (1989), Spillane (1991), Yale (1992), Herbert (1997), } \\
\text { Ashworth (2000), Fox (2002), Karyono (1987), Kaelany (2002), Howard } \\
\text { (2003), Doratli, dkk. (2004), Purwadi (2006), Timothy, Dallen dan Daniel } \\
\text { (2006), Ardika (2007), Ilman dan Purwadio (2010) Mohammad (2012) }\end{array}$ \\
\hline Potensi Pariwisata & $\begin{array}{l}\text { Damardjati (1973), Mariotti dalam Yoeti (1996), Pendit (2002), Damanik dan } \\
\text { Weber (2006) }\end{array}$ \\
\hline Tourism Bencmarking & Cano (2001), Pyo (2001), Kozak (2004), \\
\hline Manajemen Krisis & $\begin{array}{l}\text { Fink (1986), Roberts (1994), Coombs (1999), Faulkner (2001), miller dan } \\
\text { Ritchie (2003), Aktas dan Gunlu (2005) }\end{array}$ \\
\hline Sistem Pariwisata & $\begin{array}{l}\text { Mathesion dan Wall (1982), Mill dan Morison (1985), Getz (1986), McIntosh } \\
\text { dan Goldener (1986), Leiper (1990), Fennel (1999), Heath (1998), Cooper } \\
\text { (1999) }\end{array}$ \\
\hline
\end{tabular}

Sumber : Hasil Penelitian, 2018

Untuk kajian teori-teori ilmu pariwisata (KTTIP), serangkaian konsep kunci (termasuk sub-konsep) mengacu pada grand theory dan middle range theory dari ilmu pengetahuan yang sudah mapan. Seperti, ilmu antropologi budaya, arkeologi, sejarah, 
sosiologi, psikologi dan pemerintahan dengan fokus kepada nilai-nilai budaya, otentisitas, heritage, perubahan budaya, konservasipreservasi, pelestarian, revitalisasi, potensi, struktural fungsional, tradisi, ritual, partisipasi, pengembangan masyarakat, interaksi sosial, perubahan, gerakan sosial, kedekatan sosial, jarak sosial, pembelajaran sosial, peran, kelas, dampak, konflik, gender, persepsi, motivasi dan daya dukung psikologi, otonomi daerah, fungsi pemerintahan, organisasi pariwisata, kebijakan publik, tata pemerintahan, dan pelayanan prima

Ilmu ekonomi dan manajemen mencakup identifikasi potensi, permintaan pasokan, keunggulan komparatif, heckscher ohlin, kualitas layanan, kepuasan pelanggan, kinerja, multipalyer effect, pengaruh, leakage, korelasi, perencanaan, pengelolaan, harapan konsumen, kepuasan, strategi manajemen manajemen, sumber daya manusia, kewirausahaan, tingkat kesejahteraan, pendapatan, dampak, kebutuhan pengeluaran, manajemen sumber daya berbasis masyarakat. Ilmu geografi, Ilmu geografi sosial, Ilmu geowisata, Ilmu planologi dan teknik (arsitek dan lainnya) dan Ilmu lingkungan berfokus kepada pengembangan, dampak lingkungan, morfologi geologi, hidrologi, konjungtur tanah, daya dukung ekologi, penilaian ekologis lokasi kualitas fisik tanah, kualitas sungai, kualitas vegetasi, analisis tapak, kapasitas / penggunaan ruang, sanitasi dan pembangunan berkelanjutan.

Ilmu linguistik dan Ilmu komunikasi seperti, framing, content analyis, wacana, perhotelan, pemahaman lintas budaya, hospitalitas. Ilmu pemasaran dan Ilmu IT berfokus kepada analisis pemasaran konten, strategi pemasaran, strategi promosi, komunikasi pemasaran terpadu, diversifikasi produk dan kerangka pemasaran digital. Ilmu hukum dan Ilmu kriminologi seperti hukum bisnis dan keselamatan, keamanan, kenyamanan dan sosialisasi kejahatan. Ilmu postmodern mengkritisi globalisasi, ideologi, komodifikasi, komersialisasi, turistifikasi, paradigma, geneologi, semiotika, dan hermeneutika. Ada juga beberapa teori baru yang berkembang, seperti mitigasi, kesehatan, keahlian memasak dan gastronomi-kuliner.

Dari tahun 1970an, di samping teoriteori di atas, ilmu pariwisata telah mengakui serangkaian teori yang telah diprakarsai oleh para ilmuwan luar dengan latar belakang antropologis, sosiologis, ekonomi dan ilmu pengetahuan lainnya. Fakta ini sangat membantu sebagai pondasi dasar yang mendorong lahirnya ilmu pariwisata di Indonesia. Sayangnya di Indonesia, masih sedikit konsep baru, model dan teori baru dalam ilmu pariwisata. Seharusnya, untuk meningkatkan kredibiltas pariwisata sebagai ilmu, harus dilakukan penelitian yang menghasilkan novelty dan dipublikasi dalam bentuk jurnal dan buku ilmiah. Publikasi buku ISBN tentang pariwisata di Indonesia dari 1967 hingga 2011 hanya 198 buku. Buku-buku teori pariwisata mendominasi publikasi lebih dari buku-buku pengetahuan vokasional. Sebagai ilmu independen yang diakui secara resmi oleh Direktur Jenderal Pendidikan Tinggi sejak 2008, meski diakui sudah agak terlambat, tetapi telah memberikan kekuatan yang cukup untuk ilmu pariwisata semakin menunjukkan eksistensinya. Sebagaimana harus dipahami bahwa pertumbuhan dan dinamika pengetahuan bergantung pada pendidikan dan publikasi (Simpala, 2012).

Sejalan dengan konsep-konsep dalam ilmu pariwisata yang tertuang dalam Matrik 2, Kajian Konsep Ilmu Pariwisata (KKIP) di atas, dan Matrik 3 Kajian Teori-Teori Ilmu Pariwisata (KTTIP), ternyata jika ditelusuri sudah memiliki akar kuat mulai tahun 1970-an. Sampai sekarang teori-teori ilmu pariwisata terutama di luar negeri terus berkembang. Terdapat polapola berbeda jika dilihat teori-teori ilmu pariwisata mulai tahun 1970-1985, tahun 1986-2005 dan tahun 2006-2018.

Di era 1970-1985 teori-teori ilmu pariwisata memiliki pola mengarah kepada pembentukan grand theory (teori besar). Artinya teori-teori era tersebut menjadi suatu postulat (seperti pada ilmu eksakta terdapat hukum kekekalan energi dari Joule, dalil phytagoras, teori air dari Archimedes, dan yang lainnya), yang berlaku universal dan tidak terbantahkan. Hadir ilmuwan-ilmuwan pariwisata yang dikenal sampai saat ini, yang sebenarnya tidak lahir dari ilmu pariwisata itu sendiri. Namun perannya untuk pengakuan ilmu pariwisata secara tidak langsung sangat besar dan telah mendapatkan pengakuan secara akademis maupun praktis. Seperti konsep 
siklus hidup destinasi pariwisata yang terkenal sampai saat ini sebagai evolusi pariwisata oleh Butler (1980), tampak terinspirasi oleh teori irration index dari sosiolog Doxey (1976), teori evolusi masyarakat lokal dan wisatawan dari antropolog Greenwood (1977), dikembangkan sebagai konsep destination are life cycle oleh antropolog konsultan Bank Dunia bernama Noronha (1977, dalam Sutrisno dan Muhamad, 2017) bersifat linear-tidak bersifat siklus, dilanjutkan konsep pengembangan tata ruang pariwisata-masyarakat pesisir oleh planolog Stansfield, (1978, dalam Abdilah, dkk., 2015).

Di era tahun 1986-2005 teori-teori ilmu pariwisata tampak memiliki pola sebagai middle range theory, disamping ada sebagian kecil yang mengarah kepada grand theory seperti pada era sebelumnya. Tetapi pada intinya di era ini mulai mengaplikasikan teoriteori besar pada ilmu-ilmu pengetahuan yang sudah mapan karena pesatnya pembangunan pariwisata di belahan dunia. Middle range theory adalah teori yang menjelaskan sesara lebih spesifik fenomena yang diteliti, setelah menggunakan grand theory yang bersifat makro. Bukannya tidak mungkin middle range theory dapat menjadi grand theory ketika kapasitasnya mampu menjelaskan, memahami, prediksi dan hasilnya berlaku secara universal.

Pada era terakhir tahun 2006-2018 teori-teori ilmu pariwisata semakin kompleks. Dalam arti mengacu kepada dua era sebelumnya jika dapat dikatakan sebagai era grand theory ilmu pariwisata (1970-1989) dan era middle range theory ilmu pariwisata (19862005), teori-teori ilmu pariwisata di era ini mengarah kepaa pola little theory. Bahkan terkesan tidak memperdulikan teori yang masuk kategori grand theory atau middle range theory. Terpenting penelitian atau kajian yang dilakukan mampu memberikan penjelasan dan makna dari diversifikasi dunia pariwisata yang tidak lepas dari pengaruh globalisasi dan bersidat dinamis. Tidak berarti grand theory dan middle range theory tidak digunakan melainkan teori-teori yang sudah mapan tersebut tetap menjadi rujukan. Perbedaannya adalah cenderung pada tujuannya yaitu little theory atau hasil temuan penelitian (termasuk temuan konsep-konsep) di lapangan yang dianggap telah memberikan jawaban atas permasalahan pariwisata berdasarkan pendekatan (paradigma ; apakah kuantitatif atau kualitatif), metodologi (serangkaian konsep, teori dan metode), dan metode-metode ilmiah (cara untuk mendapatkan data; dapat metode kuantitatif atau metode kualitatif atau mix methods tetapi bukan mix methodology).

Fenomena pariwisata dilihat sebagai dimensi-dimensi yang saling berkaitan sebagai suatu sistem (Fridgen, 1991; Hall, 2003). Dapat berupa dimensi ekonomi, dimensi budaya, dimensi lingkungan atau dimensi lainnya yang memudah dan dapat dikaji secara interdispliner, multidispliner maun transdisiplin. Sangat cair dan luluh menyatu antara para ahli geografi, ahli psikologi, antropolog, sosiolog, planolog, ekonom dan ahli ilmu lainnya dalam melakukan kajianpenelitian fenomena pariwisata. Jika diijinkan mengatakan ini adalah era little theory ilmu pariwisata maka ilmu pariwisata akan memiliki pengayaan konsep-teori secara langsung maupun tidak langsung. Sebagai residu, adalah terutama keaktifan para mahasiswa, dosen, peneliti, yang telah bernaung dibawah ilmu pariwisata secara institusional pendidikan (univeristas, fakultas, program studi/jurusan) untuk mengikuti, menyimak, dan mengumpulkan perkembangan di era ini melalui publikasi ilmiah dan mampu mengakomodir sesuai kebutuhan bahkan jika memungkinkan melakukan pengembanganpengembangan sebagai upaya menuju kemandirian ilmu pariwisata sebagai science (termasuk inovasi-inovasi di era disruption dan Revolusi Industri 4.0).

Temuan ini sangat bermanfaat dalam menyikapi blind spot konseptual teoritis ilmu pariwisata yang masih terjadi. Sering konsep dan teori digunakan tanpa dasar pemahaman yang kuat sehingga mengesampingkan proses (termasuk mengesampingkan metode-metode) dengan mengutamakan hasil. Paling tidak blind spot konseptual teoritis ilmu pariwisata dapat 
diketahui untuk semakin hati-hati dan aktif mencari solusi yaitu dengan semakin memperbanyak penemuan-penemuan konsep dan teori pariwisata sebagai suatu novelty.

\section{KESIMPULAN}

Berdasarkan hasil penelitian yang telah dilakukan oleh tim peneliti maka diperoleh kesimpulan sebagai berikut :

1. Reidentifikasi konsep dan teori ilmu Pariwisata di Bali menunjukkan penggunaan konsep dan teori ilmu pariwisata masih mengacu kepada grand theory dan middle range theory yang sebagian besar masih masuk dalam kategori ilmu-ilmu pengetahuan lain yang sudah mapan seperti ilmu ekonomi, ilmu manajemen, ilmu arkeologi, ilmu sejarah, ilmu antropologi budaya, ilmu sosiologi, ilmu psikologi, ilmu geografi, ilmu planologi, ilmu pemasaran, dan yang lainnya.

2. Fenomena blind spot yaitu tidak terlihatnya substansi data ketika melakukan penelitian pariwisata karena kelemahan pemahaman konsep dan teori yang kompleks. Terdapat beberapa titik penting yang sebenarnya merupakan temuan berharga dalam penelitian pariwisata tetapi justru terlewatkan karena besarnya "mesin konsep dan teori". Sebenarnya besar atau kecil "mesin konsep dan teori" tidak menjadi masalah tergantung dari sasaran penelitian. Tetapi yang harus ditingkatkan adalah kesadaran reflektif untuk menelusuri, identifikasi, asumsi dasar, kelemahan dan kelebihan dari suatu konsep dan teori yang digunakan (di era revolusi industri 4.0 penelusuran pustaka semakin mudah dengan kecanggihan mesin-mesin seperti google scholar dan yang lainnya). Praxis ini tampaknya masih sedikit dilakukan dalam khasanah akademis pariwisata yang sedang ditantang untuk pembuktian pariwisata sebagai sebuah disiplin ilmu.

\section{Saran}

1. Perlu ditingkatkan penelitian-penelitian yang mampu menghasilkan konsepteori baru untuk pengembangan ilmu pariwisata di Bali. Sehingga penelitianpenelitian tidak hanya berorientasi kepada pengenalan konsep-teori atau aplikasi konsep-teori semata, namun harus memberikan novelty yang dapat dimanfaatkan secara akademis maupun praktis.

2. Fenomena blind spot konsep dan teori ilmu pariwisata dapat diatasi dengan pemahaman dan bukan menghafal konsep dan teori. Oleh karena itu pemikiran ahistori harus ditinggalkan dan memulai dengan keaktifan untuk melacak, "membedah" dan melakukan refleksi kepada konsep dan teori ilmu pariwisata sesuai dengan keperluan / minat.

3. Tulisan ini memiliki banyak kelemahan dan kedepan untuk penyempurnaan reidentifikasi konsep dan teori dalam memahami fenomena blind spot penelitian pariwisata di Bali, perlu dilakukan penelitian re-anatomi ilmu pariwisata. Hasil temuan penelitian saat ini dapat dijadikan dasar pijakan untuk pengembangan anatomi ilmu pariwisata.

\section{DAFTAR PUSTAKA}

Anonim. 2008. Surat Keputusan Direktoral Jendral Perguruan Tinggi Nomor 2425 / D / T /29 Juli 2008 dan Surat Keputusan Rektor Universitas Udayana Nomor 347A/H14/HK/2008 tanggal 27 September 2008 Tentang Pendirian Fakultas Pariwisata Universitas Udayana

Abdillah, F., Damanik, J., \& Fandeli, C. (2015). Perkembangan Destinasi Pariwisata, Benarkah Memang Meningkatkan Kualitas Hidup Masyarakat.Khasanah Ilmu-Jurnal Pariwisata Dan Perhotelan, 6(2). Google Scholaar Link.

Ahimsa-Putra, Shri Edi. 2007. "Paradigma, Epistemologi dan Metode Ilmu Sosial-Budaya, Sebuah Pemetaan". Makalah Pelatihan yang tidak dipublikasikan dalam "Pelatihan Metodologi Penelitian 12 Februari-19 Maret 2007" Yogyakarta : CRCS-Antropologi Budaya, Fakultas Ilmu Budaya, UGM.

Ari Yuana, Kumara. 2010. The Greatest Philosophers. Jogyakarta:Andi Offset.

Bakta, I Made. 2018. Pengantar Filsafat Ilmu. Denpasar : Udayana University Press.

Bungin, Burhan. 2010. Metode Penelitian Kualitatif. Jakarta. Kencana Prenama Media Group.

Fridgen, Joseph. 1991. Dimension of Tourism. East Lansing : American and Hotel Association. 
Vol. 7 No 2, 2019

Hall, Colin Michael. 2003. Introduction To Tourism : Dimension, and Issues. South Melbourne : Hospitality Press.

Mahagangga, I Gusti Agung dan Nugroho, Saptono. 2017. Pemahaman Lintas Budaya dalam Kepariwisataan. Denpasar : Cakra Press dan Fakultas Pariwisata Universitas Udayana

Moleong, Lexy. 2005. Metodelogi Penelitian Kualitatif. Bandung : Remaja Rosda Karya.Nugroho,

Muhadjir, Noeng. 1996. Metodologi Penelitian Kualitatif : Pendekatan Positivistik, Rasionalitik, Phenomenologi, dan Realisme Metaphisik Telaah Studi Teks dan Penelitian Agama. Yogyakarta : Rake Sarasin

Muhadjir, Noeng. 2000. Metode Penelitian Kualitatif. Yogyakarta : Rake Sarasin

Neuman, W. L. (2013). Social research methods: Qualitative and quantitative approaches. Seventh Edition. UK : Pearson Education.

Nugroho, Saptono. Anom, I Putu. Mahagangga, I Gusti Agung. 2017. Pengantar Filsafat Ilmu Pariwisata . Denpasar : Cakra Press dan Fakultas Pariwisata Universitas Udayana

Prajitno, S. B. (2013). Metodologi Penelitian Kuantitatif. Jurnal. Bandung: UIN Sunan Gunung Djati.(tersedia di http://komunikasi. uinsgd. ac. id). Google Scholaar Link

Prentice, A.E .1990. "Introduction" dalam Information Science - The Interdisciplinary Context. (ed. J. M. Pemberton dan A.E. Prentice). New York : Neal-Schuman Publishers

The Liang Gie. 2014. Filsafat Ilmu : klasik hingga kontemporer. Jakarta : PT. Raja Grafindo Persada.

Simpala, Mawardin M. 2012. "Kajian Kepustakaan Pariwisata 1976-2011 di Indonesia". Jurnal Kepariwisataan Indonesia. Jurnal Terakreditasi LIPI No. 487/AU2/P2MILIPI/08/2012. Jakarta : Puslitbang Kebijakan Kepariwisataan Badan Pengembangan Sumber Daya Kementerian Pariwisata dan Ekonomi Kreatif RI

Suriasumantri, J.S. 1978. Ilmu dalam Perspektif. Jakarta : PT. Gramedia.

Suryawan, Ida Bagus dan Mahagangga, I Gusti Agung. 2017. Penelitian Lapangan 1. Denpasar : Cakra Press dan Fakultas Pariwisata Universitas Udayana

Sutrisno, B. (2016). MODEL PENGEMBANGAN DESA WISATA (STUDI KOMPARATIF DESA JAYAGIRI, KECAMATAN LEMBANG DAN DESA SARONGGE, KECAMATAN PACET). Sosioglobal: Jurnal Pemikiran dan Penelitian Sosiologi, 1(1), 68-81. Google Scholaar Link. 